Turkish Psychological Counseling and Guidance Journal

Türk Psikolojik Danışma ve Rehberlik Dergisi
Yelpaze, Deniz \& Satıc1 (2021)

Vol: 11 Number: 62 Page: 367-382 ISSN: 1302-1370

RESEARCH

Open Access

ARAŞTIRMA

Açık Erişim

\title{
Association between Social Connectedness and Well-Being: A Study of the Mediating Role of Psychological Vulnerability
}

Sosyal Bağhlık ve İyi Oluş Arasindaki İlişkide Psikolojïk Kırllganlı̆̆n Aracılık Rolü

\section{İsmail Yelpaze ๑, Mehmet Engin Deniz ๑, Begüm Satıc1 $\odot$}

\begin{tabular}{l}
\hline Authors Information \\
İsmail Yelpaze \\
Assistant Professor, \\
Kahramanmaraş Sütçü İmam \\
University, Kahramanmaraş, \\
Turkey iyelpaze@,ksu.edu.tr \\
Mehmet Engin Deniz \\
Professor, Yıldı Teknik \\
University, İstanbul, Turkey \\
edeniz@,yildiz.edu.tr \\
Begüm Satıcı
\end{tabular}

Associate Professor, Artvin Çoruh University, Artvin, Turkey

begum@artvin.edu.tr

\begin{abstract}
The researcher in this study examined psychological vulnerability as a mediator between social connectedness and well-being among university students in Turkey. Two hundred sixty-one students (138 females and 123 males, mean age $=20.95 \pm 1.49)$ completed selfreport questionnaires including the Social Connectedness Scale, the Subjective Vitality Scale, the Subjective Happiness Scale, the Flourishing Scale, and the Psychological Vulnerability Scale. The researcher explored a theoretical-conceptual model and tested it using Structural Equation Modeling (SEM) and bootstrapping. SEM results showed that social connectedness had a direct effect on well-being, partially mediated by psychological vulnerability. The results indicated an indirect yet significant effect of psychological vulnerability on the relationship between social connectedness and well-being. Theoretical implications and research limitations were discussed.
\end{abstract}

\begin{tabular}{l}
\hline Article Information \\
Keywords \\
Social Connectedness \\
Psychological Vulnerability \\
Well-being \\
Structural Equation Modelling \\
Bootstrapping \\
Anahtar Kelimeler \\
Sosyal Bağlllık \\
Psikolojik Kırılganlık \\
Iyi Oluş \\
Yapısal Eşitlik Modellemesi \\
Bootstrapping \\
Article History
\end{tabular}

Received: $26 / 07 / 2021$

Revision: $15 / 09 / 2021$

Accepted: 22/09/2021

\section{ÖZET}

Bu araştırmada üniversite öğrencilerinin iyi oluşları ile sosyal bağlılıkları arasındaki ilişkide psikolojik kırılganlığın aracılık rolü incelenmiştir. 261 üniversite öğrencisi (138 kadın, 123 erkek, yaş ortalaması = $20.95 \pm 1.49)$ Sosyal Bağlllık Ölçeği, Öznel Zindelik Ölçeği, Öznel Mutluluk Ölçeği, İyilik Hali Ölçeği ve Psikolojik Kırılganlık Ölçeğini doldurmuştur. Teorik olarak kurulan model Yapısal Eşitlik Modellemesi (YEM) ve bootstrapping tekniği ile analiz edilmiştir. YEM sonuçlarına göre sosyal bağlllik iyi oluşu hem doğrudan hem de psikolojik kırılganlık aracılığıyla etkilemektedir. Bootstrapping tekniği ile psikolojik kırılganlığın sosyal bağlılık ile iyi oluş arasındaki ilişkide kısmi aracılığ1 doğrulanmıştır. Çalışmanın doğurguları ve sınırlıkları ilgili literatür çerçevesince tartışılmıştır.

Cite this article as: Yelpaze, I., Deniz, M.E., \& Satıc1, B. (2021). Association between social connectedness and well-being: A study of the mediating role of psychological vulnerability. Turkish Psychological Counseling and Guidance Journal, 11(62), 367-382. https://doi.org/10.17066/tpdrd.1001712 


\section{INTRODUCTION}

Having satisfactory relationships with others is a basic need for most of the people. According to Baumeister and Leary (1995) the need to be socially connected to others is "a fundamental human motivation" (p. 497). Feeling lonely, isolated, unrelated to others, alienated from others, and/or a lack of belonging are unpleasant experiences for most of the people. Accordingly, they strive to restore relationships, maintain friendships, participate in group activities, and avoid jeopardizing social bonds (Carroll, Bower, \& Muspratt, 2017). This process of striving for connection may have an adverse effect on well-being and mental health of the people (e.g., lack of social connections may cause psychological distress) because the individuals are more likely to experience problems to meet the need to maintain interpersonal relationships and participation in social activities (Satici, Uysal, \& Deniz, 2016).

Social connectedness is a concept which can be defined as the perceptions related to the long-term interpersonal relationships and social environment (Lee et al., 2001) and that arises from interpersonal relationships within social networks. Lee and Robbins (2000) considered that social connectedness can satisfy one's sense of belonging, and it is based on long-lasting interpersonal relationships. Also, Lee and Robbins (1998) described social connectedness as one's sense of belonging to the social world, including family, friends and colleagues and one's belief of self in relation to others.

Social connectedness occurs when an individual actively interacts with another person or group, then this interaction increases well-being and may reduce anxiety (Malaquias, Crespo, \& Francisco, 2015). On one hand, individuals who are socially connected usually see others friendly. On the other hand, individuals with low social connectedness mistrust others and avoid social opportunities (Detrie \& Lease, 2007).

Social connectedness has multi-dimensions and it comprises engagement, loneliness, affiliation, companionship, and belongingness (Arundell, Salmon, Veitch, \& Timperio, 2019; Townsend \& McWhirter, 2005). Baumeister and Leary (1995) differentiated social connectedness from belongingness, and they defined this construct by being a member of a group. Social connectedness has two main components. The first one, the relation and connection (bond) individuals experience with others. The second one is the autonomy that means the degree to which individuals feel socially supported and satisfied (Barber \& Schluterman, 2008).

\section{Social Connectedness and Well-Being}

Feeling socially connected might significantly contribute to well-being. In this study, subjective happiness, subjective vitality, and flourishing were used as the indicators of well-being. Well-being is a complex concept; therefore, the researcher decided to use more than one variable to assess well-being. There are similar studies in which the researchers used similar methodologies (e.g., Jose, Ryan, \& Pryor, 2012; Proctor, Tweed, \& Morris, 2015; Satici \& Uysal, 2015).

The happiness level of an individual has an influence on how he/she perceives, interprets, and experiences life events and situations (Lyubomirsky \& Lepper, 1999). Subjective happiness is the general evaluation of one's happiness rather than relying on positive or negative affection (Schiffrin \& Nelson, 2010). And subjective vitality refers to one's mentally and physically being (e.g., alert and energetic) (Ryan \& Frederick, 1997). Flourishing refers to one's psychological needs for competence, relatedness, and autonomy; it also refers to one's social needs for engagement and supportive relationship (Diener et al., 2010). Flourishing can also be defined as social-psychological well-being. In sum, subjective happiness, 
subjective vitality, and flourishing assess different dimensions of well-being including affective, cognitive, physical, psychological, and social.

Social connectedness might have an impact on psychological and/or individual functioning. Some research has revealed that social connectedness was related to higher levels of well-being (e.g., Griffiths et al., 2007). McLoughlin and colleagues (2019) explained that low social connectedness may result in depression, anxiety, and stress. Likewise, research has shown people with low connectedness often experience less satisfaction with their social relationships (Satici et al., 2016). They may also have problems with managing their internalizing symptoms (Faro, McKee, Garcia, \& O'Leary, 2019). Similarly, Lee and colleagues (2001) found that people with a higher sense of social connectedness to be more active in social life, establish relationships easily, and perceive their environments in a positive manner.

The researcher suggested social context variables to have a central role in assessing well-being (Helliwell, Barrington-Leigh, Harris, \& Huang, 2009). Individuals who have close relationships were found to be happier than those who do not, and the sense of belongingness to a society and social connectedness were also found to increase one's well-being (e.g., Baumeister \& Leary 1995; Liao \& Weng, 2018). Besides, social connectedness that can strengthen/improve engagement was suggested as one of the key concepts of well-being (Csikszentmihalyi, 1990).

Strong social relationships are associated with high levels of well-being while lack of social ties has negative relations with well-being (e.g., Appau, Churchill, \& Farrell, 2019). A three-year longitudinal study by Jose, Ryan, and Pryor's (2012) revealed that social connectedness increased well-being of individuals. Williams and Galliher (2006) also reported that social connectedness was related to well-being. Lastly, Brown, Hoye, and Nicholsan (2012) and Satici (2016) suggested that social engagement was a significant and positive indicator of well-being. Based on the previous literature it is obvious that social connectedness is a crucial aspect of well-being.

\section{Psychological Vulnerability as a Mediator}

Psychological vulnerability may be accepted as an inevitable result of being human, and all human beings are susceptible to psychological problems. Sinclair and Wallston (1999) defined psychological vulnerability as cognitive beliefs that reflect dependence on achievement or external sources of affirmation for one's self-worth. Developing cognitive schemas to answer anticipations of other people might increase psychological vulnerability (Sinclair \& Wallston, 2010). Individuals who are psychologically vulnerable are likely to be overly stressed by life events; therefore, they might have more negative emotions, negative schemas, a tendency to psychological disorders (Ingram, Miranda, \& Segal, 1998; Nogueira, Barros, \& Sequeira, 2018; Sinclair \& Wallston, 1999).

Researches showed that psychological vulnerability was affected by social circumstances. Claudius (2018) reported that direct negative effect of social connectedness on psychological distress. Also, more recent study indicated that lack of social connections may lead to psychological vulnerability which contribute to poorer mental health outcomes (Dang, 2014). In addition, another study by Satici, Uysal, Yilmaz, and Deniz (2016) revealed a negative relationship between psychological vulnerability and social safeness and found social safeness as a significant negative predictor of psychological vulnerability.

Psychological vulnerability was also found to be significantly and negatively related with several constructs that determine well-being. For example, researcher have determined that psychological vulnerability is a key factor that reduces the subjective happiness (Satici \& Uysal, 2017). In a cross- 
sectional study, it was claimed that psychological vulnerability is an important factor for mental health and well-being (Demirci, Ekşi, Ekşi, \& Kaya, 2019). Also, in a study based on structural equation modelling, Satici (2016) found that psychological vulnerability may undermine subjective well-being. Therefore, psychological vulnerability is a potential mediator on the link between social connectedness and well-being (as combination of subjective happiness, subjective vitality, and flourishing). To discuss the potential factors for this relationship, the empirical support is still lacking. Psychological vulnerability, social connectedness, and well-being are also clearly relevant. Based on the available evidence on the significant associations between social connectedness, psychological vulnerability and well-being, the current researchers in this study hypothesized that psychological vulnerability would mediate the association between social connectedness and well-being. In other words, higher levels of social connectedness will be associated with greater levels of well-being through lower levels psychological vulnerability. Additionally, psychological vulnerability will be negatively related to social connectedness and well-being.

Hypothesis 1. Social connectedness will predict well-being.

Hypothesis 2. Social connectedness will predict psychological vulnerability.

Hypothesis 3. Psychological vulnerability will predict well-being.

Hypothesis 4. Psychological vulnerability will act as a mediator between social connectedness and wellbeing.

\section{METHOD}

\section{Participants}

Two hundred and sixty-one volunteer university students (138 females and 123 males, mean age $=20.95$, standard deviation $=1.49$, and range from 18 to 26) were recruited from three state university in Turkey. Participants were extracted by a convenience sampling method. With respect to major, the participants identified their majors as following $104(40 \%)$ social sciences, $63(24 \%)$ sciences, $57(22 \%)$ engineering sciences, and 37 (14\%) medical sciences. Of the participants, 57 (21.8\%) were first-year, 69 (26.4\%) were second-year, $70(26.8 \%)$ were third-year, and $65(24.9 \%)$ were fourth-year students.

\section{Ethical Statement}

The authors declare that they continue to work in accordance with scientific study ethics and the Helenski declaration in this study. Accordingly, the research was reviewed by the Scientific Research and Publication Ethics Committee of Artvin Çoruh University and was given permission (Date: 28/04/2021, Number: E-18457941-050.99-10648). In addition, the participants participated in the study on a voluntary basis.

\section{Measures}

All participants completed the Subjective Vitality Scale (Ryan \& Frederick, 1997; Turkish version: Akin, Satici, Arslan, Akin, \& Kayis, 2012), the Flourishing Scale (Diener et al., 2010; Turkish version: Telef, 2013), the Subjective Happiness Scale (Lyubomirsky \& Lepper, 1999; Turkish version: Akin \& Satici, 2011), the Psychological Vulnerability Scale (PVS; Sinclair \& Wallston, 1999; Turkish version: Akin \& Eker, 2011), and the Social Connectedness Scale (Lee \& Robbins, 1995; Turkish version: Duru, 2007). 
In this current study, the researcher assessed validity and reliability of the measures. First, convergent validity was founded handling standardized loadings, and average variance extracted (AVE) value is used to examine the convergent validity of the measures. The AVE for the majority of the concepts was equal or higher than 0.50, supporting convergent validity (Henseler, Ringle, \& Sinkovics, 2009). Second, discriminant validity was examined with conducting the suggested by Fornell and Larcker (1981). The researcher suggested that the square root of the AVE should be greater than the correlations values (see Table 1). Reliabilities were determined by internal consistency analysis (Cronbach's alpha) and composite reliability (CR). The cut-off criteria of Cronbach's alpha and CR were 0.7 (Fornell \& Larcker, 1981; Nunnally, 1978). The findings are given below.

Well-Being. Three assessments of well-being (the Subjective Vitality Scale, Flourishing Scale, and the Subjective Happiness Scale) were utilized in this study. Higher scores represent higher levels of wellbeing, as it is the case for the rest of the scales. The Subjective Vitality Scale consists of seven items (e.g., "I look forward to each new day"), and each item is scored on a seven-point Likert scale, ranging from 1 (not at all true) to 7 (very true). The Turkish version of the scale has been confirmed unidimensional structure (RMSEA=.047, NFI=.99, CFI=1.00, $\mathrm{IFI}=1.00, \mathrm{RFI}=1.00, \mathrm{GFI}=.99$, and $\mathrm{AGFI}=.96$ ), and it demonstrated to have good internal reliability $(\alpha=.84$, Akin et al., 2012; test-retest $=.64$, Ryan $\&$ Frederick, 1997). In this study, AVE value was found to be 0.50 , suggesting convergent validity at the construct level. Also, the square root of AVE is greater than the related correlation value, indicating adequate discriminant validity. Finally, the Cronbach's alpha (0.84) and CR (0.87) were found at an acceptable level, indicating adequate reliability.

The Flourishing Scale consists of eight items (e.g., "I lead a purposeful and meaningful life"), and each item is scored on a seven-point Likert scale, ranging from 1 (strong disagreement) to 7 (strong agreement). The Turkish version of the scale has been confirmed unidimensional structure $\left(\chi^{2}=92.90, \mathrm{df}=20\right.$, RMSEA $=.08, \mathrm{NFI}=.94, \mathrm{CFI}=.95, \mathrm{IFI}=.95, \mathrm{RFI}=.92, \mathrm{GFI}=.96$, and $\mathrm{SRMR}=.04)$ and demonstrated to have good internal reliability $(\alpha=.80$ and test-retest=.86; Telef, 2013). In this study, AVE value was found to be 0.51 , suggesting convergent validity at the construct level. Also, the square root of AVE is greater than the related correlation value, which indicates adequate discriminant validity. Finally, the Cronbach's alpha (0.89) and CR (0.89) were found acceptable level, indicating good reliability.

The Subjective Happiness Scale consists of four items (e.g., "In general, I consider myself”) with a sevenpoint Likert scale, ranging from 1 (not a very happy person) to 7 (a very happy person). The Turkish version of the scale has been confirmed unidimensional structure $(\mathrm{NFI}=.99, \mathrm{CFI}=1.00, \mathrm{GFI}=1.00$, $\mathrm{AGFI}=.99, \mathrm{RFI}=.98$, and $\mathrm{SRMR}=.015)$ and demonstrated to have acceptable internal reliability $(\alpha=.86$ and test-retest $=.73$, Akin \& Satici, 2011). In this study, AVE value was found to be 0.50 , suggesting convergent validity at the construct level. Also, the square root of AVE is greater than the related correlation value, indicating adequate discriminant validity. Finally, the Cronbach's alpha (0.76) and CR (0.79) were found at an acceptable level, indicating adequate reliability.

Social Connectedness. Social connectedness was measured with the Social Connectedness Scale. The scale consists of eight items (e.g. "I don't feel related to anyone"). Participants rated the extent to which an item described them with a six-point scale, ranging from 1 (strongly disagree) to 6 (strongly agree). The Turkish version of scale has been confirmed unidimensional structure $(\chi 2 / \mathrm{df}=4.25$, NNFI $=0.95$, $\mathrm{CFI}=0.95, \mathrm{SRMR}=0.065$, and RMSEA $=.09$; Kurtyilmaz, Can, \& Ceyhan, 2017) and demonstrated to have acceptable internal reliability ( $\alpha=.91$ and test-retest=.90; Duru, 2007). In this study, AVE value was 
found to be 0.62, suggesting convergent validity at the construct level. Also, the square root of AVE is greater than the related correlation value, indicating adequate discriminant validity. Finally, the Cronbach's alpha (0.93) and CR (0.93) were found acceptable level, indicating excellent reliability.

Psychological Vulnerability. Psychological vulnerability was measured with the Psychological Vulnerability Scale. The scale consists of six items (e.g., "I often feel resentful when others take advantage of me") and each item is scored on a five-point Likert scale, ranging from 1 (does not describe me at all) to 5 (describes me very well). The score from each item is calculated to obtain an overall score, with higher score indicating higher psychological vulnerability level. The Turkish version of the scale has been confirmed unidimensional structure $(\mathrm{NFI}=.97, \mathrm{CFI}=1.00, \mathrm{GFI}=.99, \mathrm{AGFI}=.98, \mathrm{RFI}=.95, \mathrm{SRMR}=.025$, and RMSEA $=.00)$ and demonstrated to have good internal reliability $(\alpha=.75$; Akin $\&$ Eker, 2011 and testretest=.83; Sinclair \& Wallston, 1999). In this study, AVE value was found to be 0.54 , suggesting convergent validity at the construct level. The square root of AVE is also greater than the related correlation value, indicating adequate discriminant validity. Finally, the Cronbach's alpha (0.87) and CR (0.87) were found at an acceptable level, indicating good reliability.

\section{Procedure}

Data was collected from the participants who were accessible and voluntary. The measures were distributed to students in the physical classrooms on campus. The order of the questionnaires was counterbalanced. Participation was voluntary and unnamed, and the participants were permitted to withdraw from the study at any time. Informed consent was provided before participation. The participants answered the measures at their own pace, and it took approximately 10 minutes to complete.

\section{Analysis}

First, univariate (means, standard deviations, skewness, and kurtosis) and bivariate statistics (correlations) were carried out using IBM SPSS Statistics 22. Matrix factorable was also checked via Kaiser-MeyerOlkin and Bartlett's sphericity test. After descriptive statistics, multivariate inferential analyses were computed using SEM. SEM was performed through AMOS Graphics. The SEM was performed following a two-step process. First, to examine the psychometric properties of the measures, a measurement model was done through a confirmatory factor analysis. In order to handle well-being as a latent variable, the researchers performed second order confirmatory factor analysis (CFA) with Flourishing, Subjective Vitality, and Subjective Happiness Scales. When the measurement model was confirmed, we examined the mediational model via the maximum likelihood estimation. The researcher used the CFA, because it has a number of fit indices that can be used to test for the model fit. The fit indexes used in this study are (1) chi-square ( $\chi 2)$, (2) Comparative Fit Index (CFI), (3) Incremental Fit Index (IFI), (4) Standardized Root-Mean-Square Residual (SRMR), and (5) Root Mean Square Error of Approximation (RMSEA). To compare two or more models, chi square difference test $(\Delta \chi 2)$, Akaike Information Criterion (AIC), and Expected Cross-Validation Index (ECVI) values were used to determine which model was preferred. In addition, the mediating role of psychological vulnerability between social connectedness and well-being was tested for significance by adopting the bootstrapping estimation procedure (a bootstrapping sample of 10,000 was specified). 


\section{RESULTS}

\section{Descriptive Statistics}

Initial evaluation of the data distributions indicated no extreme outliers on any of the variables. Normality of the data was examined by kurtosis and skewness for each variable. Means, standard deviations, skewness, kurtosis, and inter-correlations for all the study variables are presented in Table 1.

\begin{tabular}{|c|c|c|c|c|c|c|c|c|c|}
\hline \multirow[b]{2}{*}{ Variable } & \multicolumn{5}{|c|}{ Bivariate correlations } & \multicolumn{4}{|c|}{ Descriptive Statistics } \\
\hline & 1 & 2 & 3 & 4 & 5 & $M$ & $S D$ & Skewnes & Kurtosis \\
\hline 1. Social connectedness & .79 & & & & & 38.57 & 7.53 & -.94 & .67 \\
\hline $\begin{array}{l}\text { 2. Psychological } \\
\text { vulnerability } \\
95 \% \mathrm{CI}\end{array}$ & $\begin{array}{c}-.28^{* *} \\
(-.37,-.18)\end{array}$ & .73 & & & & 16.45 & 4.23 & .17 & .13 \\
\hline $\begin{array}{l}\text { 3. Subjective vitality } \\
95 \% \mathrm{CI}\end{array}$ & $\begin{array}{c}.39^{* *} \\
(.30, .47)\end{array}$ & $\begin{array}{c}-.25^{* *} \\
(-.34,-.15)\end{array}$ & .71 & & & 34.14 & 7.19 & -.52 & .83 \\
\hline $\begin{array}{l}\text { 4. Subjective happiness } \\
95 \% \mathrm{CI}\end{array}$ & $\begin{array}{c}.42^{* *} \\
(.33, .50)\end{array}$ & $\begin{array}{c}-.31^{* *} \\
(-.40,-.21)\end{array}$ & $\begin{array}{l}.51^{* *} \\
.43, .58)\end{array}$ & .71 & & 19.73 & 3.87 & -.13 & .01 \\
\hline $\begin{array}{l}\text { 5. Flourishing } \\
95 \% \mathrm{CI}\end{array}$ & $\begin{array}{c}.34^{* *} \\
(.24, .43)\end{array}$ & $\begin{array}{c}-.29^{* *} \\
(-.41,-.16)\end{array}$ & $\begin{array}{l}.37^{* *} \\
(.28, .46)\end{array}$ & $\begin{array}{c}.33^{* *} \\
(.23, .42)\end{array}$ & .72 & 42.47 & 8.33 & -.49 & -.39 \\
\hline
\end{tabular}

Note. $^{* *} p<.01$, Diagonals (in bold) represents square root of AVE while off diagonals represent correlations

The skewness (range $=-0.94-0.17$ ), and kurtosis (range $=-0.39-0.83$ ) values indicated that the distributions of all the variables were normal. In order to check the matrix factorable, Bartlett's test was used. In the study, the Kaiser-Meyer-Olkin measure of sampling adequacies was found to be $0.86,0.72$, 0.91, 0.84, and 0.93; the $\chi^{2}$ value of Bartlett's sphericity test were found to be $842.02(\mathrm{df}=21), 306.42(\mathrm{df}=6)$, 1013.30 $(\mathrm{df}=28), 371.74(\mathrm{df}=15)$, and 1385.34 $(\mathrm{df}=28)$ for subjective vitality, subjective happiness, flourishing, psychological vulnerability, and social connectedness, respectively (all $p$ s $<.001$ ). Also, eigenvalues indicated that the number of factors appears to be as dictated by theory or as in any original versions of the measures (see Table 2). The Scree plot also showed that one factor should be retained. The unidimensionality of the subjective vitality, subjective happiness, flourishing, psychological vulnerability, and social connectedness were verified and explained $54.45 \%, 59.88 \%, 57.29 \%, 46.68 \%$, and $66.75 \%$ of the variance, respectively.

The results revealed that the correlations between social connectedness and subjective vitality $(r=.39$, 95\% CI: .30, .47), subjective happiness $(r=.42,95 \%$ CI: .33, .50), and flourishing $(r=.34,95 \%$ CI: .24, .43) were positive. Psychological vulnerability correlated negatively with social connectedness $(r=-.28$, 95\% CI: -.37, -.18), subjective vitality $(r=-.25,95 \% \mathrm{CI}:-.34,-.15)$, subjective happiness $(r=-.31,95 \% \mathrm{CI}$ : $-.40,-.21)$, and flourishing $(r=-.2995 \% \mathrm{CI}:-.41,-.16)$.

\section{Measurement Model}

First, CFA was used to investigate the construct validity of each latent variable. The factor loadings, Cronbach's alpha coefficient, composite reliability, and covariance between latent variables on final measurement model are presented in Table 2. 
Table 2. Factor loadings, Cronbach's alpha coefficient and covariance between latent variables on measurement model

\begin{tabular}{|c|c|c|c|c|c|c|c|c|c|}
\hline \multirow[b]{2}{*}{ Item } & \multirow{2}{*}{$\begin{array}{l}\text { Factor } \\
\text { Loading }\end{array}$} & \multirow{2}{*}{$\begin{array}{l}\text { Latent } \\
\text { Variable }\end{array}$} & \multirow[b]{2}{*}{$\begin{array}{l}\text { Factor } \\
\text { Loading }\end{array}$} & \multirow{2}{*}{\multicolumn{2}{|c|}{ Cronbach $\alpha \mathrm{CR}$}} & \multirow[b]{2}{*}{ Latent variable } & \multicolumn{3}{|c|}{ Covariance } \\
\hline & & & & & & & $\begin{array}{l}\text { Well- } \\
\text { being }\end{array}$ & $\begin{array}{c}\text { Psychological } \\
\text { vulnerability }\end{array}$ & $\begin{array}{c}\text { Social } \\
\text { connectedness }\end{array}$ \\
\hline 1. Vit1 & .83 & $\begin{array}{l}\text { Subjective } \\
\text { vitality }\end{array}$ & .77 & .84 & .87 & Well-being & - & - & - \\
\hline 2. Vit2 & .37 & & & & & & & & \\
\hline 3. Vit3 & .69 & & & & & & & & \\
\hline 4. Vit4 & .90 & & & & & & & & \\
\hline 5. Vit5 & .65 & & & & & & & & \\
\hline 6. Vit6 & .50 & & & & & & & & \\
\hline 7. Vit7 & .83 & & & & & & & & \\
\hline 8. Hap1 & .89 & $\begin{array}{l}\text { Subjective } \\
\text { happiness }\end{array}$ & .86 & .76 & .79 & & & & \\
\hline 9. Hap2 & .76 & & & & & & & & \\
\hline 10. Нар3 & .54 & & & & & & & & \\
\hline 11. Hap4 & .57 & & & & & & & & \\
\hline 12. Flo1 & .72 & Flourishing & .53 & .89 & .89 & & & & \\
\hline 13. Flo2 & .77 & & & & & & & & \\
\hline 14. Flo3 & .65 & & & & & & & & \\
\hline 15. Flo4 & .62 & & & & & & & & \\
\hline 16. Flo5 & .65 & & & & & & & & \\
\hline 17. Flo6 & .79 & & & & & & & & \\
\hline 18. Flo7 & .79 & & & & & & & & \\
\hline 19. Flo8 & .72 & & & & & & & & \\
\hline 20. Pv1 & .76 & & & .87 & .87 & $\begin{array}{l}\text { Psychological } \\
\text { vulnerability }\end{array}$ & $-.43^{\dagger}$ & - & - \\
\hline 21. Pv2 & .70 & & & & & & & & \\
\hline 22. Pv3 & .75 & & & & & & & & \\
\hline 23.Pv4 & .85 & & & & & & & & \\
\hline 24. Pv5 & .67 & & & & & & & & \\
\hline 25. Pv6 & .65 & & & & & & & & \\
\hline 26. Sc1 & .78 & & & .93 & .93 & $\begin{array}{l}\text { Social } \\
\text { connectedness }\end{array}$ & $.61^{\dagger}$ & $-.33^{\dagger}$ & \\
\hline 27. Sc2 & .75 & & & & & & & & \\
\hline 28. Sc3 & .83 & & & & & & & & \\
\hline 29. Sc4 & .80 & & & & & & & & \\
\hline 30. Sc5 & .80 & & & & & & & & \\
\hline 31. Sc6 & .79 & & & & & & & & \\
\hline 32. Sc7 & .79 & & & & & & & & \\
\hline 33. Sc8 & .76 & & & & & & & & \\
\hline
\end{tabular}

Note. ${ }^{\dagger} p<.01$; eigenvalues 3.81 for subjective vitality, 2.40 for subjective happiness, 4.58 for flourishing, 2.91 for psychological vulnerability, 5.34 for social connectedness; CR composite reliability

A CFA of the Psychological Vulnerability Scale indicated good fit data: $\chi^{2}(9, \mathrm{~N}=261)=16.345, p<.001$; $\mathrm{CFI}=.98 ; \mathrm{IFI}=.98, \mathrm{SRMR}=.032 ; \mathrm{RMSEA}=.056$. Similarly, Social Connectedness Scale suggested good fit data as follows: $\chi^{2}(20, \mathrm{~N}=261)=72.238, p<.001 ; \mathrm{CFI}=.96$; IFI=.96, SRMR=.035; RMSEA=.076. Second order CFA of the three-factor model (subjective vitality, flourishing and subjective happiness) of well-being indicated good fit data: $\chi^{2}(149, \mathrm{~N}=261)=371.272, p<.001 ; \mathrm{CFI}=.91$; IFI=.91, SRMR=.061; RMSEA =.076.

In addition, the researcher conducted the CFA with all latent variables, social connectedness, psychological vulnerability and well-being (for well-being second order used). The CFA for all latent variable together measurement model as follows: $\chi^{2}(489, \mathrm{~N}=261)=847.972, p<.001$; CFI=.92; IFI=.92, $\mathrm{SRMR}=.061$; RMSEA $=.053$ C.I. [.047, .059]. Confirming the construct validity in the measurement 
models, all standardized factor loadings of the scale items on their respective higher-order constructs were of considerable size $(.37-.90)$ and highly significant (all $p$ s $<.001)$. These findings provided evidence of construct validity of the measures used in the current research.

\section{Structural Model}

The current researcher initially examined the direct path from the predictor (social connectedness) to the dependent (well-being), in the absence of mediator being significant, $\beta=0.61, p<0.01$. Then, we assessed a full mediation model in which paths were drawn from social connectedness to psychological vulnerability and from psychological vulnerability to well-being. Significant path coefficients were found from social connectedness to psychological vulnerability $(\beta=-.38, p<.001)$ and from psychological vulnerability to well-being $(\beta=-.52, p<.001)$. The goodness-of-fit statistics for this model showed good fit to the data except for SRMR: .098, $\chi^{2}\left({ }_{117, \mathrm{~N}=261}\right)=245.636, p<.001 ; \mathrm{CFI}=.93$; IFI=.94, RMSEA=.065 C.I. $[.054, .076]$.

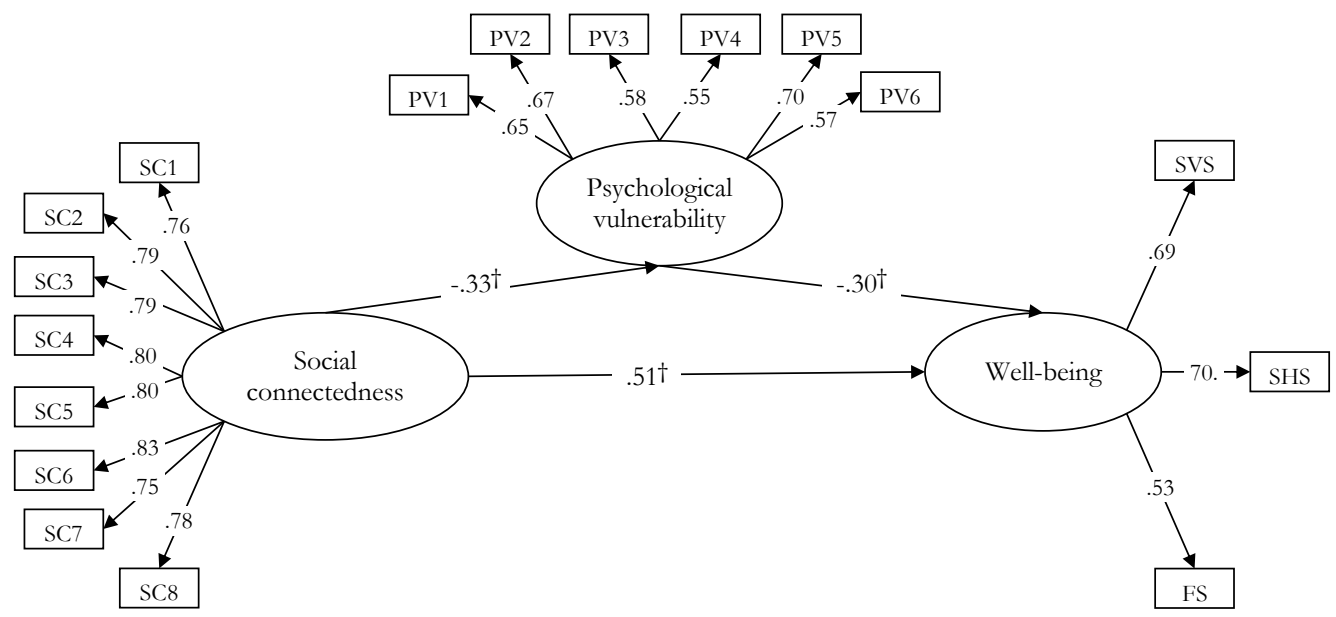

Figure 1. Standardized parameter estimates for the partially-mediated model.

Notes: $N=261 ; \dagger p<.01, S C$ item of the Social Connectedness Scale; $P V$ item of the Psychological Vulnerability Scale; SVS Subjective vitality; SHS Subjective happiness; FS Flourishing

Then we investigated an alternative partial mediation model in which direct paths were added from social connectedness to well-being to establish whether psychological vulnerability mediated the relationship between social connectedness and well-being, or whether there were direct effects. Social connectedness had a positive effect on well-being $(\beta=.51, p<.001)$ and a negative effect on psychological vulnerability $(\beta=-.33, p<.001)$. The meditational model showed a very good fit to the data: $\chi^{2}(116, \mathrm{~N}=261)=197.255$, $p<.001 ; \mathrm{CFI}=.96 ; \mathrm{IFI}=.96, \mathrm{SRMR}=.049 ; \mathrm{RMSEA}=.052$ C.I. $[.039, .064]$. The effect of social connectedness on well-being through psychological vulnerability was $46 \%$.

The chi-square difference test between partially mediated model and fully mediated model was significant $\left(\Delta \chi^{2}=48.38, \mathrm{df}=1, \mathrm{p}<.05\right)$, which suggests that partially mediated model was better. Also, partially mediated model's AIC (271.25) and ECVI (1.04) values were smaller than fully mediated model's AIC (317.36) and ECVI (1.22) values; therefore, the partially mediated model was preferred (Figure 1).

Table 3 shows the indirect effects and their associated bootstrapping 95\% confidence intervals. As shown, social connectedness had a significant direct effect on well-being. In addition, the indirect effect of social connectedness on well-being through psychological vulnerability was also significant (empirical $95 \%$ confidence interval does not overlap with zero). The analyses revealed that psychological 
vulnerability had a partial mediation effect on the relationship between social connectedness and wellbeing levels of the participants.

Table 3. Bootstrapping results

\begin{tabular}{|c|c|c|c|}
\hline \multirow[b]{2}{*}{ Model pathways } & \multirow[t]{2}{*}{ Estimated } & \multicolumn{2}{|c|}{$95 \% \mathrm{CI}$} \\
\hline & & Lower & Upper \\
\hline \multicolumn{4}{|l|}{ Direct effect } \\
\hline Social connectedness $\rightarrow$ Psychological vulnerability & -0.229 & -0.357 & -0.119 \\
\hline Social connectedness $\rightarrow$ Well-being & 2.960 & 1.968 & 4.046 \\
\hline Psychological vulnerability $\rightarrow$ Well-being & -2.526 & -4.079 & -1.305 \\
\hline \multicolumn{4}{|l|}{ Indirect effect } \\
\hline Social connectedness $\rightarrow$ Psychological vulnerability $\rightarrow$ Well-being & 0.578 & 0.235 & 1.158 \\
\hline
\end{tabular}

\section{DISCUSSION}

Psychological vulnerability causes individuals to be subjected to psychopathology and influences wellbeing and it is associated with perfectionism, negative thoughts and dependency on external sources (Sinclair \& Wallston, 1999). Psychological vulnerability may be related to indicators of social functioning and subjective happiness, subjective vitality, and flourishing, which are significant determinants of wellbeing (Satici et al., 2016; Sinclair \& Wallston, 1999). Thus, the current study focused on the question of whether psychological vulnerability plays a mediating role in the association between social connectedness and well-being.

Results indicated that psychological vulnerability partially mediated the relationship between social connectedness and well-being. In other words, the effect of social connectedness on well-being was partially mediated by being vulnerable to psychological problems. Experiencing high levels of social connectedness reduced being susceptible to psychopathology, which in turn contributed to well-being. Although a number of studies have consistently highlighted that psychological vulnerability may be related negatively with social connectedness (e.g., Satici et al., 2014) and well-being (Sinclair \& Wallston, 1999), no research has addressed mediation in these relationship. Satici and colleagues (2016) demonstrated that psychological vulnerability was inversely related to life satisfaction that is one of the basic dimensions of well-being and social safeness, which has a strong association with being related to feelings of belonging and acceptance. Similarly, Satici and colleagues (2014) found that psychological vulnerability was negatively associated with social competence. Some other researchers found that greater levels of social connectedness and well-being were significantly related to lower levels of depression that might be occurred as result of psychological vulnerability (Armstrong \& Ooneb-Early, 2009). Additionally, Akin, Demirci, and Yildiz (2015) suggested that insight, as a positive predictor of psychological well-being (Harrington \& Loffredo, 2011), was negatively related to psychological vulnerability. Thus, the findings of the current study are consistent with previous studies.

As anticipated, results of the analysis have shown that both social connectedness and well-being are negatively related to psychological vulnerability. This is consistent with previous studies propounding relationships among these variables (Sinclair \& Wallston, 1999). Saricam (2015) showed that social vulnerability or susceptibility to social abuse positively related with psychological vulnerability. Tomas, Sancho, Melendez, and Mayordomo (2012) stated that resilience is a significant predictor of general wellbeing. Moreover, and in accordance with earlier literature (Appau, Churchill, \& Farrell, 2019; Liao, \& Weng, 2018; Satici et al., 2016), it was found social connectedness was positively related to well-being. 


\section{Limitation and Future Directions}

With regard to the research methods, some limitations need to be acknowledged. Firstly, this study relied on self-report measures which may lower the internal validity of the data. Therefore, in order to increase the internal validity, future studies may benefit from different techniques such as peer assessment and observation. Similarly, observation, peer evaluation, and sociometric ratings can be used for the evaluation of social connectedness. Similar techniques as well as self-report measures can be employed in order to measure well-being. It will be sensible to include sociodemographic variables such as wealth status, health and upbringing styles, which influence well-being. Furthermore, qualitative studies can be conducted in order to explore the phenomenon of well-being.

The second limitation is the participants were students from one university in Turkey. Therefore, it limits to generalize the results of the present research. In addition, this study used a cross-sectional design which cannot establish cause and effect relationships. The association between social connectedness and psychological vulnerability might be reversed with vulnerability leading to social connectedness. Future studies may use longitudinal and experimental research design which would provide more conclusive evidence of causal relationships.

\section{Implications}

The present researchers examined the predictor role of social connectedness, which is defined as a sense of belongingness to one's environment and psychological vulnerability (meaning the tendency to perceive stimuli negatively) on well-being of university students. Results showed that high levels of social connectedness were related to lower levels of psychological vulnerability and higher levels of well-being. In this respect, university campuses should be arranged in a way in which students are able to socialize and interact with each other. Thereby, a sense of belongingness can be created for the students. Counseling centers can play important roles in making these activities to be both more effective and systematical. The centers also can provide activities where the students express themselves safely and interact with one another effectively, which in turn contribute to well-being. Well-structured psychoeducational programs can be designed for students who have high levels of psychological vulnerability. These programs can focus on the students and how they perceive their environment including what they are expecting from others and how they can be helpful for their environment. Additionally, the concept of resilience along with communication skills should be considered in these programs, which might significantly contribute to students' levels of social connectedness and psychological vulnerability. Based on all these, it is crucial to realize and pay attention to that well-being of students is significantly influenced by their psychological and social assumptions about themselves and their environment. 


\section{REFERENCES}

Akin, A., \& Eker, H. (2011, July). Turkish version of the Psychological Vulnerability Scale: A study of validity and reliability. Paper presented at the 32th International Conference of the Stress and Anxiety Research Society, Munster, Germany.

Akin, A., \& Satici, S. A. (2011). Subjective Happiness Scale: A study of validity and reliability. Sakarya University Journal of Education Faculty, 21, 65-77. https://dergipark.org.tr/tr/download/article-file/115639

Akin, A., Demirci, İ., \& Yildiz, E. (2015). Personal self-concept as mediator and moderator of the relationship between insight and psychological vulnerability. International Online Journal of Educational Sciences, 7(1), 79-86. https://doi.org/10.15345/iojes.2015.01.007

Akin, A., Satici, S. A., Arslan, S., Akin, U., \& Kayis, A. R. (2012, February). The validity and the reliability of the Turkish Version of the Subjective Vitality Scale (SVS). Paper presented at the $4^{\text {rd }}$ World Conference on Educational Sciences, Barcelona, Spain.

Appau, S., Churchill, S. A., \& Farrell, L. (2019). Social integration and subjective wellbeing. Applied Economics, 51(16), 1748-1761. https://doi.org/10.1080/00036846.2018.1528340

Armstrong, S., \& Oomen-Early, J. (2009). Social connectedness, self-esteem, and depression symptomatology among collegiate athletes versus nonathletes. Journal of American College Health, 57(5), 521-526. https://doi.org/10.3200/JACH.57.5.521-526

Arundell, L., Salmon, J., Veitch, J., \& Timperio, A. (2019). The relationship between objectively measured and selfreported sedentary behaviours and social connectedness among adolescents. International journal of Environmental Research and Public Health, 16(2), 277. https://doi.org/10.3390/ijerph16020277

Barber, B. K., \& Schluterman, J. M. (2008). Connectedness in the lives of children and adolescents: A call for greater conceptual clarity. Journal of Adolescent Health, 43(3), 209-216. https://doi.org/10.1016/j.jadohealth.2008.01.012

Baumeister, R. F., \& Leary, M. R. (1995). The need to belong: desire for interpersonal attachments as a fundamental human motivation. Psychological bulletin, 117(3), 497-529. https://doi.org/10.1037/0033-2909.117.3.497

Brown, K. M., Hoye, R., \& Nicholson, M. (2012). Self-esteem, self-efficacy, and social connectedness as mediators of the relationship between volunteering and well-being. Joumal of Social Service Research, 38(4), 468-483. https://doi.org/10.1080/01488376.2012.687706

Carroll, A., Bower, J. M., \& Muspratt, S. (2017). The conceptualization and construction of the Self in a Social Context-Social Connectedness Scale: A multidimensional scale for high school students. International Journal of Educational Research, 81, 97-107. https://doi.org/10.1016/j.ijer.2016.12.001

Claudius, M. (2018). Discrimination, Trauma, and Psychological Distress among Central American Immigrants: The Role of Social Connectedness and Belonging (Doctoral dissertation, Boston College. Lynch School of Education).

Csikszentmihalyi, M. (1990). Flow: The psychology of optimal experience. Harper \& Row

Dang, M. T. (2014). Social connectedness and self-esteem: Predictors of resilience in mental health among maltreated homeless youth. Issues in Mental Health Nursing, 35(3), 212-219. https://doi.org/10.3109/01612840.2013.860647

Demirci, İ., Ekşi, H., Ekşi, F., \& Kaya, Ç. (2019). Character strengths and psychological vulnerability: The mediating role of resilience. Current Psychology, 1-11. https://doi.org/10.1007/s12144-019-00533-1

Detrie, P. M., \& Lease, S. H. (2007). The relation of social support, connectedness, and collective self-esteem to the psychological well-being of lesbian, gay, and bisexual youth. Journal of Homosexuality, 53(4), 173-199. https://doi.org/10.1080/00918360802103449 
Diener, E., Wirtz, D., Tov, W., Kim-Prieto, C., Choi, D. W., Oishi, S., \& Biswas-Diener, R. (2010). New well-being measures: Short scales to assess flourishing and positive and negative feelings. Social Indicator Research, 97, 143-156. https://doi.org/10.1007/s11205-009-9493-y

Duru, E. (2007). Sosyal Bağlılık Ölçeği'nin Türk kültürüne uyarlanması [An adaptation study of Social Connectedness Scale in Turkish culture]. Eurasian Journal of Educational Research (EJER), 26, 85-94. http://ejer.com.tr/ODOWNLOAD/pdfler/tr/1307977339.pdf

Duru, E. (2008). The predictive analysis of adjustment difficulties from loneliness, social support, and social connectedness. Educational Sciences: Theory \& Practice, 8(3), 849. https://eric.ed.gov/?id=EJ837769

Faro, A. L., McKee, L. G., Garcia, R. L., \& O'Leary, J. L. (2019). Emotion socialization, social connectedness and internalizing symptoms in emerging adults. Journal of Applied Developmental Psychology, 64, 101051. https://doi.org/10.1016/j.appdev.2019.101051

Fornell, C., \& Larcker, D. F. (1981). Evaluating structural equation models with unobservable variables and measurement error. Journal of Marketing Research 18(1), 39-50. https://doi.org/10.2307/3151312

Griffiths, R., Horsfall, J., Moore, M., Lane, D., Kroon, V., \& Langdon, R. (2007). Assessment of health, well-being, and social connections: A survey of women living in Western Sydney. International Journal of Nursing Practice, 13(1), 3-13. https://doi.org/10.1111/j.1440-172X.2006.00606.x

Harrington, R., \& Loffredo, D. A. (2011). Insight, rumination, and self-reflection as predictors of well-being. The Journal of Psychology, 145, 39-57. https://doi.org/10.1080/00223980.2010.528072

Helliwell, J. F., Barrington-Leigh, C. P., Harris, A., \& Huang, H. (2009). International evidence on the social context of well-being (No. w14720). National Bureau of Economic Research.

Henseler, J., Ringle, C. M., Sinkovics, R. R. (2009). The use of partial least squares path modeling in international marketing. In R. R. Sinkovics, \& P. N. Ghauri (Eds.), Advances in International Marketing (pp. 277-320). Bingley: Emerald.

Ingram, R. E., Miranda, J., \& Segal, Z. V. (1998). Cognitive vulnerability to depression. Guilford Press.

Jose, P. E., Ryan, N., \& Pryor, J. (2012). Does social connectedness promote a greater sense of well-being in adolescence over time?. Journal of Research on Adolescence, 22(2), 235-251. https://doi.org/10.1111/j.15327795.2012.00783.x

Lee, R. M., \& Robbins, S. B. (1995). Measuring belongingness: The Social Connectedness and Social Assurance Scales. Journal of Counseling Psychology, 42(2), 232-241. https://doi.org/10.1037/0022-0167.42.2.232

Lee, R. M., \& Robbins, S. B. (1998). The relationship between social connectedness and anxiety, self-esteem, and social identity. Journal of Counseling Psychology, 45, 338-345. https://doi.org/10.1037/0022-0167.45.3.338

Lee, R. M., \& Robbins, S. B. (2000). Understanding social connectedness in college women and men. Journal of Counseling and Development, 78, 484-491. https://doi.org/10.1002/j.1556-6676.2000.tb01932.x

Lee, R. M., Draper, M., \& Lee, S. (2001). Social connectedness, dysfunctional interpersonal behaviors, and psychological distress: Testing a mediator model. Journal of Counseling Psychology, 48(3), 310-318. https://doi.org/10.1037/0022-0167.48.3.310

Liao, K. Y. H., \& Weng, C. Y. (2018). Gratefulness and subjective well-being: Social connectedness and presence of meaning as mediators. Journal of Counseling Psychology, 65(3), 383-393. https://doi.org/10.1037/cou0000271

Lyubomirsky, S., \& Lepper, H. S. (1999). A measure of subjective happiness: Preliminary reliability and construct validation. Social Indicators Research, 46, 37-155. https://doi.org/10.1023/A:1006824100041

Malaquias, S., Crespo, C., \& Francisco, R. (2015). How do adolescents benefit from family rituals? Links to social connectedness, depression and anxiety. Journal of child and Family Studies, 24(10), 3009-3017. https://doi.org/10.1007/s10826-014-0104-4 
McLoughlin, L. T., Spears, B. A., Taddeo, C. M., \& Hermens, D. F. (2019). Remaining connected in the face of cyberbullying: Why social connectedness is important for mental health. Psychology in the Schools 56, 945-958. https://doi.org/10.1002/pits.22232

Nogueira, M. J., Barros, L., \& Sequeira, C. (2017). Psychometric properties of the Psychological Vulnerability Scale in higher education students. Journal of the American Psychiatric Nurses Association, 23(3), $215-222$. https://doi.org/10.1177/1078390317695261

Nunnally, J. C. (1978). Psychometric theory (2nd ed.). McGraw-Hill.

Proctor, C., Tweed, R., \& Morris, D. (2015). The naturally emerging structure of well-being among young adults:"Big Two" or other framework?. Journal of Happiness Studies, 16(1), 257-275. https://doi.org/10.1007/s10902-014-9507-6

Ryan R. M. \& Frederick, C. (1997). On energy, personality and health: Subjective vitality as a dynamic reflection of well-being. Journal of Personality, 65, 529-565. https://doi.org/10.1111/j.1467-6494.1997.tb00326.x

Saricam, H. (2015). The Turkish version of the Social Vulnerability Scale: The study of validity and reliability. International Online Journal of Educational Sciences, 7(1), 190-202. https://doi.org/10.15345/iojes.2015.01.016

Satici, B., Saricali, M., Satici, S. A., \& Eraslan-Capan, B. (2014). Social competence and psychological vulnerability as predictors of Facebook addiction. Studia Psychologica, 56(4), 301-308. https://doi.org/10.21909/sp.2014.04.738

Satici, S. A. (2016). Forgiveness, vengeance, social connectedness and subjective well-being of university students: A study on examining different structural models. [Unpublished doctoral dissertation]. Eskisehir: Anadolu University.

Satici, S. A., \& Uysal, R. (2015). Well-being and problematic Facebook use. Computers in Human Behavior, 49, $185-$ 190. https://doi.org/10.1016/j.chb.2015.03.005

Satici, S. A., Uysal, R., \& Deniz, M. E. (2016). Linking social connectedness to loneliness: The mediating role of subjective happiness. Personality and Individual Differences, 97, 306-310. https://doi.org/10.1016/i.paid.2015.11.035

Satici, S. A., Uysal, R., Yilmaz, M. F., \& Deniz, M. E. (2016). Social safeness and psychological vulnerability in Turkish youth: The mediating role of life satisfaction. Current Psychology, 35(1), 2228. https://doi.org/10.1007/s12144-015-9359-1

Schiffrin, H. H., \& Nelson, S. K. (2010). Stressed and happy? Investigating the relationship between happiness and perceived stress. Journal of Happiness Studies, 11(1), 33-39. https://doi.org/10.1007/s10902-008-9104-7

Sinclair, V. G., \& Wallston, K. A. (1999). The development and validation of the Psychological Vulnerability Scale. Cognitive Therapy and Research, 23(2), 119-129. https://doi.org/10.1023/A:1018770926615

Sinclair, V. G., \& Wallston, K. A. (2010). Psychological vulnerability predicts increases in depressive symptoms in individuals with rheumatoid arthritis. Nursing Research, 59(2), 140-146. https://doi.org/10.1097/nnr.0b013e3181d1a6f6

Telef, B. B. (2013). The adaptation of Psychological Well-Being into Turkish: A validity and reliability study. Hacettepe University Journal of Education, 374-384. http://www.efdergi.hacettepe.edu.tr/yonetim/icerik/makaleler/237-published.pdf

Tomas, J. M., Sancho, P., Melendez, J. C., \& Mayordomo, T. (2012). Resilience and coping as predictors of general well-being in the elderly: A structural equation modeling approach. Aging \& Mental Health, 16(3), 317-326. https://doi.org/10.1080/13607863.2011.615737

Townsend, K. C., \& McWhirter, B. T. (2005). Connectedness: A review of the literature with implications for counseling, assessment, and research. Journal of Counseling and Development, 83(2), 191-201. https://doi.org/10.1002/i.1556-6678.2005.tb00596.x 
Williams, K. L., \& Galliher, R. V. (2006). Predicting depression and self-esteem from social connectedness, support, and competence. Journal of Social and Clinical Psychology,25(8), 855-874. https://doi.org/10.1521/jscp.2006.25.8.85 


\begin{abstract}
About Authors
İsmail Yelpaze. He completed his undergraduate education in the field of Guidance and Psychological Counseling at Boğaziçi University in 2010. Afterwards, he completed his master's degree in 2012 at Gaziantep university and; completed doctorate at Anadolu University in 2016. He is currently an assistant professor in the Guidance and Psychological Counseling at the Kahramanmaraş Sütçü İmam University.
\end{abstract}

Mehmet Engin Deniz. He completed his undergraduate education at Selcuk University, Psychological Counseling and Guidance Department in 1994. He received his Master's degree at 1997 and his doctorate degree at 2002 in the field of Psychological Services in Education at Selcuk University. He is still working as a professor at Yildı Technical University, Faculty of Education, Psychological Counseling and Guidance Department.

Begüm Satic1. She completed her undergraduate education at Istanbul University, Psychology Deparment in 2011. She received his Master's degree in the field of Psychological Counseling and Guidance at Anadolu University in 2014. She received his doctorate degree in the field of Psychological Counseling and Guidance at Yildız Technical University in 2018. She is still working as an assocciate professor at Artvin Çoruh University, Psychological Counseling and Guidance Department.

\title{
Author Contributions
}

This study was conducted by all the authors working together and cooperatively. All of the authors substantially contributed to this work in each step of the study.

\section{Conflict of Interest}

It has been reported by the authors that there is no conflict of interest.

\section{Funding}

This study was supported by Kahramanmaraş Sütçü İmam University, Scientific Research Projects Coordination Unit (Project Number: 2021/3-30 M).

\section{Ethical Statement}

This study was completed in accordance with the Helsinki Declaration. In line with this, the study was permitted by Research and Publication Ethics Committee of Artvin Çoruh University.

Ethics Committee Name: Research and Publication Ethics Committee of Artvin Çoruh University. Approval Date: 28/04/2021

Approval Document Number: E-18457941-050.99-10648 